\title{
Investigating the Compressive Strength of Pet Bottles as Masonry
}

\author{
Shubina, Abhishek Tiwari* and R.K. Sharma \\ Civil Engg. Deptt. Swami Vivekanand Subharti University Meerut, India \\ Received 22 May 2018, Accepted 25 July 2018, Available online 27 July 2018, Vol.8, No.4 (July/Aug 2018)
}

\begin{abstract}
In India if look towards urbanization a trend of use of non-renewable products like plastic bottles, have been increased, but increase of the such product recycling or destroying is the main concern. PET bottles have the different factors such as, load capacity, reducing waste material, time of execution, cost, and flexibility. PET bottles have more compressive strength compared to some conventional building material such as brick. So we can easily replace conventional brick by PET bottles. In experimental study we found that the compressive strength of mixed soil having fine and coarse partical is greater the first class brick.
\end{abstract}

Keywords: PET bottles, sustainable development, urban wastage, compressive strength.

\section{Introduction}

PET is short for polyethylene terephthalate, the chemical name for polyester. PET is a clear, durable, and low weight plastic that is extensively used for packaging beverages, especially convenience-sized soft drinks, juices and water. One of the essential disadvantages in constructing world house is high cost of the building. High cost of fundamental concern for constructing the houses in places on where people are under poverty line, is forming one of the most significant problems of people.

Plastics are produced from the oil that is considered as nonrenewable resource. Because plastic has the inviolability about 300 years in the nature, it is assumed as a sustainable waste and environmental pollutant. So reusing or recycling of it can be effectual in mitigation of environmental impacts relating to it. When the society gets affected, then it will be uneconomical for the nation to create sustainable development. Plastic bottle can assist to obtain a social equity by avoiding the gap between the rich and the poor people in the society.

With population growth in today's world, the need to the building has increased and to respond to this demand, the countries tend to use the industrial building materials and decline the use of indigenous and traditional materials. These factors in spite of increasing the energy utilization in the industry section; they can also increase the cost of homes and are considered as the blockade for users to obtain the basic needs of the life.

*Corresponding author's ORCID ID: 0000-0003-3614-8077 DOI: https://doi.org/10.14741/ijcet/v.8.4.20
PET bottles are completely filled with sand or soil or landfill dirt or mud and are used as bricks to construct houses and even water tanks. A normal brick which requires raw material and a process in its making, the plastic bottle brick requires just waste plastic bottles which are available in affluence and filling material such as mud, fly ash or sand depending upon the possibility.

PET bottles are one of the most disposable materials in the modern world. It makes up much of the street side litter in urban and rural areas. It is immediately filling up landfills as stacking water bodies. Plastic bottles make up approx. $11 \%$ of the content landfills, causing serious environmental consequences.

\section{Material used}

\subsection{PET bottle}

Polyethylene Terephthalate Ethylene (PET) bottles are thermoplastic materials. PET is ultimately derived from petroleum hydrocarbons. It is created by a reaction between terephthalic acid $\left(\mathrm{C}_{8} \mathrm{H}_{6} \mathrm{O}_{4}\right)$ and ethylene glycol $\left(\mathrm{C}_{2} \mathrm{H}_{6} \mathrm{O}_{2}\right)$. Although the ,PETE bottle when filled with soil is not theoretically homogenous and continuous, it will be considered as a composite material because it is made of two materials: PETE bottles and soil, but we assumed as a homogeneous material

\subsection{Soil}

Samples were extracted from excavated homogenous layers and below roughly two meter from the top of soil to make sure that all the organic matters were not included in sample. Sample were taken from the Subharti University campus. 
Table 1 Showing the specification of coarse soil

\begin{tabular}{|c|c|}
\hline Soil type & Size in $\mathrm{mm}$ \\
\hline Coarse soil & $0.6-2.0$ \\
\hline Medium soil & $0.2-0.6$ \\
\hline Fine soil & $0.06-0.2$ \\
\hline
\end{tabular}

\subsection{Nylone rope}

Nylon rope is extracted from coal, petroleum, air and water. It is a polyamide thermoplastic produced by series of condensation reaction between an amine and organic acids. Nylone rope helps to tie the PET bottle while making wall of it. The properties of nylon as follow:

- Good abrasion resistance.

- Tough and strong but flexible too.

- High impact strength.

- Absorb water which causes reduction in strength and impact properties

- Resistant to most of the solvents and chemicals

\section{Experimental study}

\subsection{Compressive strength of brick}

Table 2 Showing the data of compressive strength of brick

\begin{tabular}{|c|c|c|c|c|}
\hline Sr.no. & Sample & $\begin{array}{c}\text { Size of } \\
\text { bricks }\end{array}$ & $\begin{array}{c}\text { Load } \\
\text { applied } \\
(\mathrm{kn})\end{array}$ & $\begin{array}{c}\text { Compressive } \\
\text { strength } \\
\left(\mathrm{n} / \mathrm{mm}^{2}\right)\end{array}$ \\
\hline 1 & A & $22.05 \times 10.5$ & 230.4 & 9.95 \\
\hline 2 & B & $23 \times 11.0$ & 245.6 & 9.29 \\
\hline 3 & C & $22.05 \times 11$ & 242.2 & 9.09 \\
\hline
\end{tabular}

Average compressive strength of brick $=9.44 \mathrm{~N} / \mathrm{mm}^{2}$

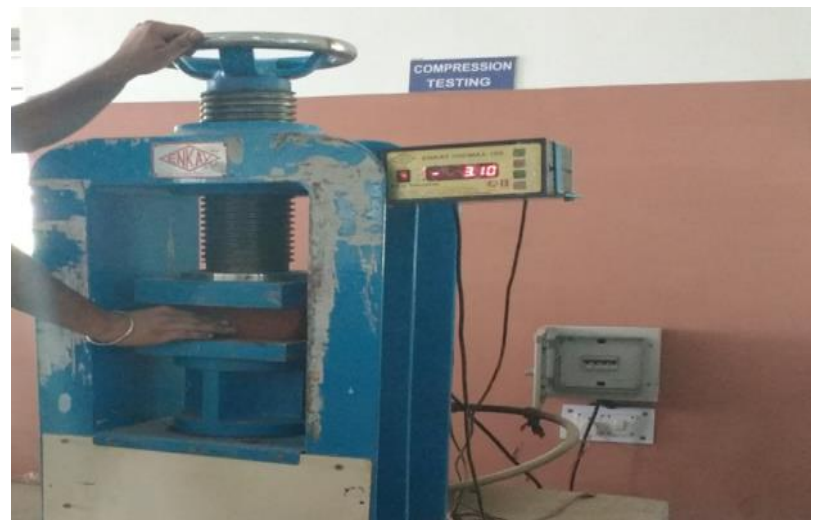

Fig.1 Compression testing on brick

Compressive strength is very important property of the bricks as different bricks are used in different types of works. Firstly we remove asymmetry observed the bed faces to provide two smooth lateral faces by grinding .Immerse the bricks in water at room temperature for 24 hours .Remove the specimen and drain out any unused moisture at room temperature. Fill the frog and all voids in the bed faces level with cement mortar (1 cement, 1 clean coarse sand of grade $3 \mathrm{~mm}$ and down). Store it under the damp jute bags for 24 hours filled by immersion in clean water for 3 days. Remove and clean out any traces of moisture. Apply load axially at a reliable rate of $14 \mathrm{~N} / \mathrm{mm} 2$ per minute till failure occurs and note maximum load at failure. The test is performed for the first class brick and its result is compared with the PET bottles compressive strength.

\subsection{Compressive strength test for PET bottles}

3.2.1 Compressive strength test for PET bottles filled with coarse soil

Table 3 Compressive strength data for PET Soda bottles filled with coarse soil

\begin{tabular}{|c|c|c|c|}
\hline Sr.no. & Sample & $\begin{array}{c}\text { Load applied } \\
(\mathrm{n})\end{array}$ & $\begin{array}{c}\text { Compressive } \\
\text { strength }(\mathrm{n} / \mathrm{mm} 2)\end{array}$ \\
\hline 1 & A & 192.6 & 10.25 \\
\hline 2 & B & 198.2 & 10.55 \\
\hline 3 & C & 197.3 & 10.50 \\
\hline
\end{tabular}

Average compressive strength $=10.43 \mathrm{~N} / \mathrm{mm}^{2}$

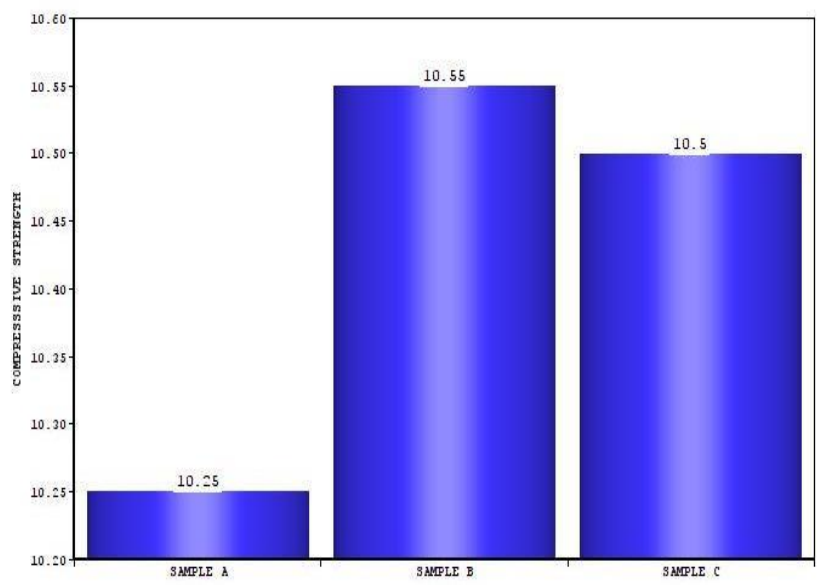

Fig.2 Showing variation of compressive strength of PET bottle with coarse soil

3.2.2 Compressive strength test for PET bottles filled with fine soil

Table 4 Compressive strength data for PET Soda bottles filled with fine soil

\begin{tabular}{|c|c|c|c|}
\hline Sr.no. & Sample & $\begin{array}{c}\text { Load } \\
\text { applied (n) }\end{array}$ & $\begin{array}{c}\text { Compressive } \\
\text { strength }\left(\mathrm{n} / \mathrm{mm}^{2}\right)\end{array}$ \\
\hline 1 & A & 242.3 & 12.90 \\
\hline 2 & B & 241.7 & 12.87 \\
\hline 3 & C & 248.6 & 13.24 \\
\hline
\end{tabular}

Average compressive strength $=13.00 \mathrm{~N} / \mathrm{mm}^{2}$ 


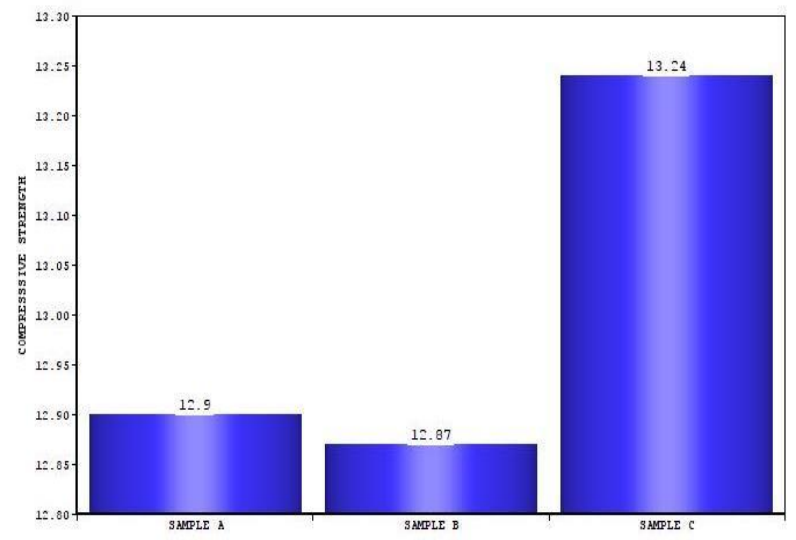

Fig.3 Showing variation of compressive strength of PET bottle with fine soil

3.3 Compressive strength test for PET bottles filled with mix soil: In Mix soil $50 \%$ particle of soil are finer

Table 5 Compressive strength data for PET Soda bottles filled with mix soil

\begin{tabular}{|c|c|c|c|}
\hline Sr.no. & Sample & $\begin{array}{c}\text { Load applied } \\
(\mathrm{n})\end{array}$ & $\begin{array}{c}\text { Compressive } \\
\text { strength }\left(\mathrm{n} / \mathrm{mm}^{2}\right)\end{array}$ \\
\hline 1 & A & 284.1 & 15.13 \\
\hline 2 & B & 286.3 & 15.25 \\
\hline 3 & C & 288.5 & 15.36 \\
\hline
\end{tabular}

Average compressive strength $=15.24 \mathrm{~N} / \mathrm{mm}^{2}$

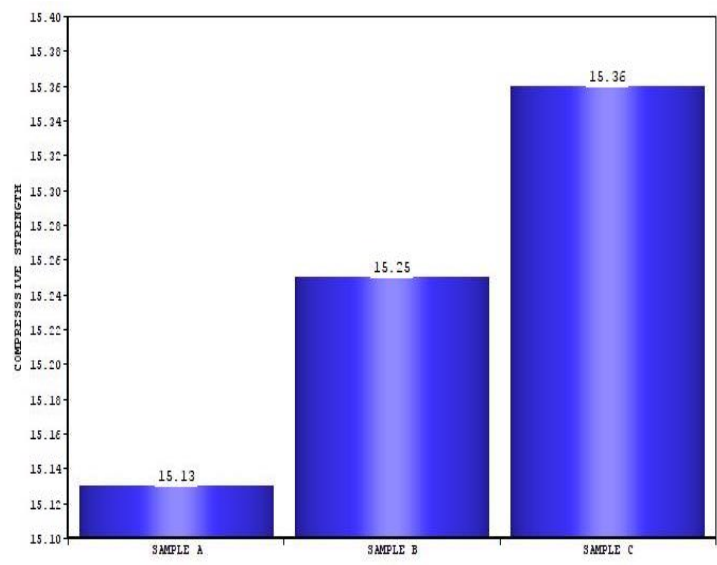

Fig.4 Showing variation of compressive strength of PET bottle with mix soil

\section{Conclusions}

1. Compressive strength of PET bottle filled with $50 \%$ fine and $50 \%$ coarse soil is larger than brick compressive strength.

2. Mostly the bottle houses are bio-climatic in design, which means that when it is cold farther is warm inside and vice versa.

3. Re-using the PET bottles as the building materials can have consequential effects on minimizing the building energy by using them rather of bricks in walls and compressing the $\mathrm{CO} 2$ emission in manufacturing the cement by reducing the percentage of cement used.

4. PET bottles construction developed the green building construction by saving energy and belongings,

Minimizing the radiation, having compelling operational savings and increasing work place productivity.

5. No curing is necessary if waste PET bottles are used as building material as compared to bricks.

6. While baking of bricks there are a major issue of carbon radiation which is minimum in using PET bottles.

\section{References}

Aditya Singh Rawat, R. Kansal 2014, PET Bottles as Sustainable Building Material: A Step Towards Green Building Construction, ISSN: 2349-879X Volume 1, Krishi Sanskriti Publications

K.Ramadevi, R. Manju 2012 , Experimental Investigation on the Properties of Concrete With Plastic PET (Bottle) Fibres as Fine Aggregate, (ISSN 2250-2459, Volume 2, IJETAE.

A.S.Sajane, Sachin E.Agam, Rakshita R. Patil , Aakanksha A. Shirgave, Sagar Y. Pituk 2017, Construction of houses using plastic bottles , ISSN 2394 - 3386 Volume 4 , IJETSR

Aditya Raut Mohammad Salman Patel Nilesh B. Jadhwar Mohammed Jalaluddin 2017, Use of Plastic Waste in Civil Constructions and Innovative Decorative Material (EcoFriendly), volume 4 MED CRAVE. 